\title{
FERNANDO GARCÍA MERCADAL. CLÁSICO Y VERNÁCULO: REFLEXIONES SOBRE EL LENGUAJE ARQUITECTÓNICO
}

\author{
ÁNGELES LAYUNO ${ }^{1}$ \\ Universidad de Alcalá
}

\begin{abstract}
La trayectoria poliédrica de Fernando García Mercadal permite reflexionar sobre la premisa de la a-historicidad del lenguaje racionalista moderno, partiendo de la confluencia en su obra de múltiples matices al margen o fusionados con la vanguardia. Desde los años de su formación como pensionado en Roma, Mercadal elabora una híbrida articulación de su lenguaje arquitectónico, vinculando las formas de la modernidad a sus estudios sobre el clasicismo y el vernáculo mediterráneo. A partir de esta premisa, el análisis de su producción escrita, construida o proyectada trata de desvelar los ingredientes clásico-vernáculos en su obra, y, a su vez, el grado de coherencia entre su pensamiento y su lenguaje arquitectónico.

Palabras clave: Movimiento Moderno; España; García Mercadal; Clasicismo; Arquitectura vernácula; Arquitectura Mediterránea.
\end{abstract}

\section{FERNANDO GARCÍA MERCADAL. CLASSICAL AND VERNACULAR:}

REFLECTIONS ON ARCHITECTURAL LANGUAGE

The multifaceted trajectory of Fernando García Mercadal allows for reflection on a topic associated with modern rationalist language: the premise of its a-historicity, starting with the isolation in his work of multiple nuances, in the margin or fused with the avant-garde. From his formative years as a pensioner in Rome, Mercadal elaborated a hybrid articulation of his architectural language, linking the forms of modernity to his studies on classicism and the Mediterranean vernacular. From this premise, this analysis of his written, constructed or projected production aims to reveal the transcendence of elements associated with the classical-vernacular in his work, and, in turn, the degree of coherence between his thinking and his architectural language.

Key words: Modern Movement; Spain; García Mercadal; Clasical tradition; Vernacular Architecture; Mediterranean architecture.

Cómo citar este artículo / Citation: Layuno, Ángeles (2019): "Fernando García Mercadal. Clásico y vernáculo: reflexiones sobre el lenguaje arquitectónico". En: Archivo Español de Arte, vol. 92, núm. 367, Madrid, pp. 301-318. https://doi.org/10.3989/aearte.2019.20.

El análisis crítico de la obra de Fernando García Mercadal ha suscitado controvertidas interpretaciones por parte de la historiografía de la arquitectura española, las cuales, desde la perspectiva contemporánea, permiten reabrir los juicios oscilantes de su obra, entre su encumbramiento como pionero y figura clave en el desarrollo del racionalismo español, por un $l_{a d o}^{2}$, y el cuestionamiento de su lenguaje y cultura vanguardista, por otro. En los años setenta del siglo pasado, el influyente estudio de Juan Daniel Fullaondo en las páginas de Nueva Forma desdibuja con énfasis la dimensión

\footnotetext{
1 angeles.layuno@uah.es / ORCID iD: http://orcid.org/0000-0002-8802-7480.
}

2 Flores, 1989. 
de Mercadal como arquitecto racionalista, lamentando su caída en "formalismos heterodoxos" a partir de los años treinta ${ }^{3}$. Este enfoque crítico sería continuado desde ámbitos académicos por las investigaciones efectuadas por Carlos Sambricio y Carlos de San Antonio, estudios que contribuyeron a desmontar la imagen de Fernando García Mercadal transmitida por los primeros textos hagiográficos, apostando por nuevas visiones críticas que en síntesis señalaron el formalismo de su aportación, la incomprensión de los compromisos sociales y técnicos de la nueva arquitectura, el contexto periférico y de tono conservador del racionalismo madrileño ${ }^{4} \mathrm{y}$, como consecuencia, la apuesta por una tercera y válida vía de modernidad sin vanguardia frente a la dicotomía tradición o vanguardia ${ }^{5}$.

\section{¿Deserción, pragmatismo o sincretismo?}

Como afirma el historiador y crítico William Curtis, "La historia no funciona como una cinta transportadora que se mueve entre un punto y otro. Una tradición puede estar regida por normas dominantes o principios rectores, pero también puede incluir líneas diversas, énfasis regionales, bucles internos, disyunciones y continuidades..." Manfredo Tafuri y Franceso Dal Co, establecían una posición reflexiva cuya trascendencia posterior fue notable al afirmar que "...la propia formación del concepto "movimiento moderno", como intento de acreditar una doctrina colectiva y teleológica de la nueva arquitectura, es el fruto de una fábula consoladora, pero inoperante", planteando un enfoque relativista y antidogmático consistente en establecer muchos inicios para muchas historias ${ }^{7}$.

A pesar de que García Mercadal intentó justificar su "deserción" de la vanguardia en aras de obtener mayores oportunidades de trabajo, sería conveniente matizar su célebre afirmación "GATEPAC o trabajo" la tradición clásica y vernácula fue un recurso que, como en el caso de otros arquitectos de su generación, representó una convicción de su pensamiento arquitectónico ${ }^{9}$. Es preciso señalar que su formación académica, la influencia de arquitectos como Vicente Lampérez, Teodoro Anasagasti o Leopoldo Torres Balbás, su papel de figura puente entre la denominada generación del 25 y el GATEPAC, su contacto con arquitectos europeos cuyo lenguaje renunciaba a la iconografía de la modernidad, su trabajo como técnico municipal madrileño en el ámbito del patrimonio y los jardines históricos, su apasionada producción investigadora en torno a las arquitecturas populares y regionales, y su trabajo como arquitecto del Instituto Nacional de Previsión desde 1946, le condujeron a un terreno en que la prexistencia, el tejido construido o el argumento de la tradición contribuyeron a debilitar el deslumbramiento inicial producido por la vanguardia racionalista.

Las primeras elaboraciones en torno a la arquitectura clásica y mediterránea se producen en la trayectoria de García Mercadal durante los años de su Pensión en Roma, entre 1923 y 1927, y son indiscutiblemente fruto de sus viajes y experiencias hacia la búsqueda de una metodología proyectual moderna realizada con el concurso de las arquitecturas clásicas y populares. No obstante, en paralelo y con posterioridad al descubrimiento de las formas del Mediterráneo, García Mercadal exploró el mundo rural y las arquitecturas populares y regionales, influido sin duda por la metodología de estudio propugnaba por Torres Balbás consistente en dibujar viviendas humildes y arquitecturas civiles, como "lección inimitable de lógica, de buen sentido, de sano casticismo" ${ }^{10}$. El papel pionero de Mercadal en el estudio de la ar-

Fullaondo, 1971: 2-8.

4 San Antonio, 2001: 69-76. Guerrero, 2008: 51

5 Sambricio, 1983: 131-140; 1984: 97. San Antonio, 2001. Rodríguez, 2003.

6 Curtis, 2006: 14.

7 Tafuri, Dal Co, 1989: 5-7.

${ }^{8}$ Frase extraída de una declaración de Mercadal, en mesa redonda compartida con Rafael Bergamín, y Casto Fernández Shaw, en la revista hogar y arquitectura, 70, Mayo-Junio 1967, p. 39.

${ }^{9}$ Layuno, 2011: 55.

10 Torres Balbás, 1922: 342. 
quitectura popular se tradujo tempranamente en La casa popular en España $(1930)^{11}$, siguiendo las iniciativas a favor de la cultura popular que desde las décadas finales del XIX habían promovido en España entidades como la Institución Libre de Enseñanza.

\section{Clasicismo y modernidad}

Si en el contexto ideológico de la arquitectura moderna, los términos tradición e historia se revistieron de significados sospechosos de contener un enfoque tradicional de la arquitectura, no obstante, la tradición ofrecía prácticas y elementos re-aprovechables para generar el proyecto moderno, como era el caso de la arquitectura popular o el clasicismo. Como apunta Alan Colquhoun, en relación a la construcción de las genealogías de la arquitectura moderna, la modernidad de la vanguardia no consistió solamente en una proyección hacia el futuro, sino que los ingredientes clásicos y vernáculos le proporcionaron un contexto que contenía dentro de sí una memoria histórica ${ }^{12}$.

En relación a este punto, resulta oportuno considerar las opiniones de Torres Balbás en su ensayo "La enseñanza de la Historia de la Arquitectura", publicado en la revista Arquitectura en 1923, en el que contrapone la postura de aquellos que rechazan el pasado y la tradición como elementos castrantes de la creación contemporánea, a los que defienden, con mentalidad moderna, el avance a partir de formas ya establecidas, la resolución histórica de problemas "eternos" de la arquitectura ${ }^{13}$.

Desde la eclosión de la modernidad, en las primeras décadas del siglo XX, el clásico, no debía entenderse según la tradición académica y decimonónica como un estilo, sino como un método racional abstracto válido para el proyecto moderno, desmitificando el concepto de racionalismo y el funcionalismo vinculado a la preeminencia del lenguaje maquinista moderno.

Mercadal asimila el clasicismo como opción lingüística compatible con la modernidad desde la premisa de que la arquitectura moderna debía asumir cierta densidad histórica a nivel conceptual y formal, y en este sentido su obra se inscribe en el contexto ideológico de la arquitectura de la generación del 25, en que se produce una consciente y voluntaria separación del formalismo ortodoxo de la modernidad. A su vez, a través de sus viajes por Europa, Mercadal entra en contacto con obras y arquitectos adscritos al clasicismo moderno, según la denominación aplicada por Manfredo Tafuri y Francesco Dal Co ${ }^{14}$, reflejado en la personalidad de Peter Behrens, August Perret, Adolf Loos, Heinrich Tessenow, Paul Bonatz, o Hans Poelzig.

En la obra arquitectónica de Mercadal, por otro lado, el clasicismo no constituye un ingrediente homogéneo, sino que su lenguaje evoluciona, en ocasiones no linealmente, en función de su trayectoria, encargos y contextos, desde una composición e iconografía historicista y monumental hacia un racionalismo clasicista moderno, como se traduce con coherencia en sus proyectos, escritos, dibujos y fotografías.

Una de las inflexiones más conservadoras de su lenguaje se materializa en el ejercicio Gran Templo en la pradera alta dedicado a San Isidro, realizado en 1923 como examen para optar a la pensión en Roma, e inspirado en modelos del Renacimiento y del Barroco clasicista. Al margen de su monumental solución en terrazas ascendentes desde el río Manzanares a la pradera superior, Mercadal emplea diversas citas históricas en cada parte del conjunto, culminando en el propio templo y en la planta centralizada de la iglesia, que envuelve el potente tabernáculo de corte herreriano situado bajo la gran cúpula, siendo este último una arquitectura in nuce, germinal, una arquitectura dentro de otra arquitectura, que condensa y resume la solución lingüística adoptada [fig. 1] ${ }^{15}$.

11 García Mercadal, 1981: 7-11.

12 Colquhoun, 1991: 38.

13 Torres Balbás, 1923: 36-40

14 Tafuri y Dal Co, 1989: 93-107

15 referentes como el patio de los evangelistas de El Escorial, el templete de Bramante en Roma, la iglesia de San Francisco el Grande en Madrid, del barroco y neoclasicismo madrileño, entre otros. Archivo RABASF, pl. 39 a 43. Díez Ibargoitia, 2015: 329-331. 


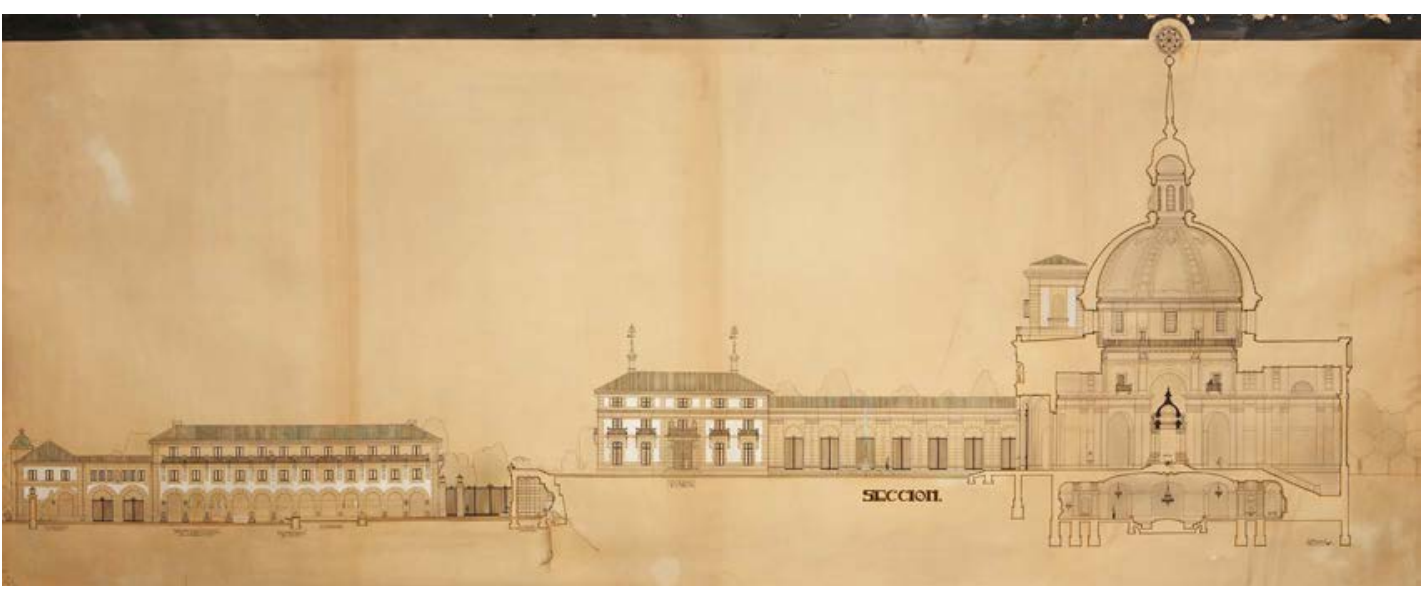

Fig. 1. Fernando García Mercadal, Templo erigido por los agricultores de España a San Isidro su patrón en la pradera. 1923. Alzados con edificios secundarios y sección de la iglesia (Archivo RABASF, 5-83-2).

Este ejercicio, fruto de su formación académica, contrasta con una de sus aportaciones teóricas mejor argumentadas, en la que Mercadal expresa, sólo un año después, una clara postura personal enfrentada al clasicismo historicista. Se trata del ensayo "Del clásico, de su enseñanza y sus relaciones con la arquitectura moderna" (1924), en el que el arquitecto afirma que es un error,

[...] creer que para producir una obra clásica nos son indispensables los entablamentos y las columnas, los capiteles dóricos o los jónicos; creemos que esto es quedarse en la cáscara, porque, si bien son las formas, no es el espíritu vivificador, medio, pero no el fin; el espíritu es el módulo, es el orden, el fin, la serenidad, y así, tan clásica como el Partenón puede ser una casita de hormigón armado con ventanas sleeppeng, si a la creación de ésta presidió el orden, el módulo, la razón, como lo fue a la de los templos de Grecia o de Sicilia ${ }^{16}$.

En efecto, siguiendo los pasos de su maestro Anasagasti, Mercadal defiende el carácter suprahistórico y anti-epidérmico del clasicismo como lenguaje, aprovechando para realizar una profunda crítica a la enseñanza académica basada en la copia de modelos históricos. Pero más sorprendente es que la elaboración del monumental ejercicio de examen de pensionado anteriormente comentado dista sólo tres años del primer proyecto construido de Mercadal y obra clave del racionalismo español, el Rincón Goya de Zaragoza (1926-1928), también un "monumento conmemorativo" concebido durante su estancia en Roma, lo cual revela la profunda transformación operada en su obra como consecuencia de los viajes y contactos con la vanguardia centroeuropea y francesa llevados a cabo desde Roma. No obstante, el polémico "Rincón Goya", que encumbra a Mercadal como arquitecto moderno ${ }^{17}$ influido por el neoplasticismo de Theo van Doesburg, evidencia sus raíces en la arquitectura popular mediterránea ${ }^{18}$, lo que permite constatar la inicial doble articulación de su lenguaje proyectual.

Las tensiones entre tradición y modernidad en el seno de su pensamiento se equilibran magistralmente en un ejemplo paradigmático de la evolución de su lenguaje sincrético, el Anteproyecto de Museo de Arte Moderno para Madrid, ganador del IV Concurso Nacional de Arquitectura en 1933. El proyecto, no ejecutado, asume un modelo epistemológico que le lleva a oponerse a la imitación de los estilos históricos, pero a su vez a dudar de las teorías radicalmente rupturistas de la vanguardia internacional. Constancia que aparece en la Memoria del proyecto, en la que Mercadal realiza una declaración de intenciones que revela la madurez de su pensamiento arquitectónico

\footnotetext{
16 García Mercadal, 1924: 150.

17 Flores, 1989: 175 y 182-183. Guerrero, 2008: 48-51.

18 Hernández, 2017: 281 y 283-285. La obra publicada en Arquitectura, 111, julio 1928, 226-231.
} 
Fig. 2a. Fernando García Mercadal, Anteproyecto de Museo de Arte Moderno para Madrid. 1933. Perspectiva (Arquitectura, 173, 1933).

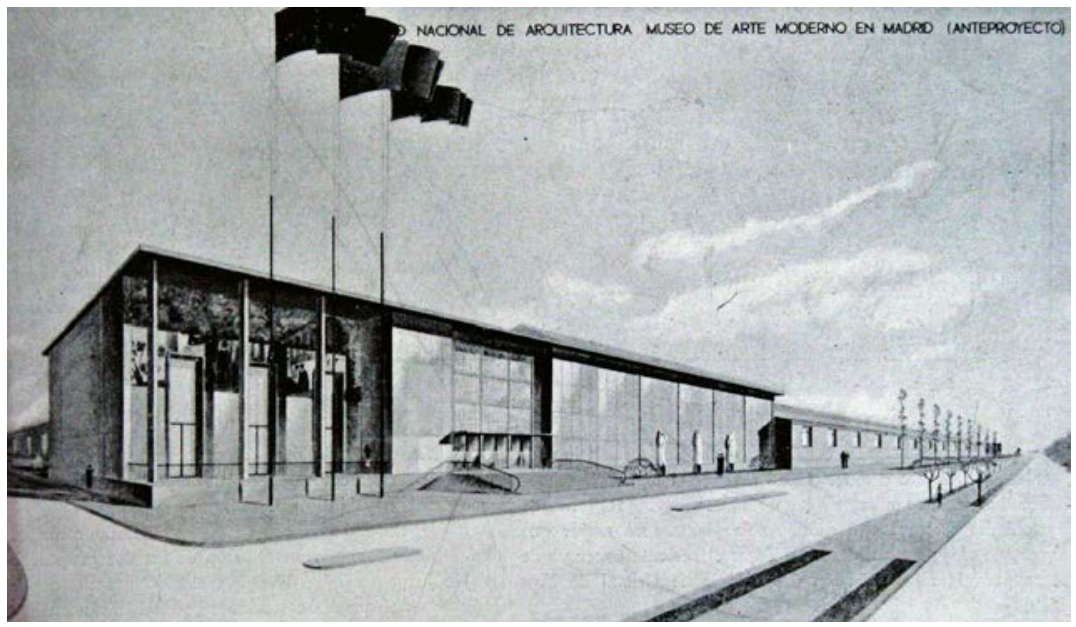

Fig. 2b. Fernando García Mercadal-Jorge Brunet: Maqueta del proyecto de Museo de Arte Moderno. 1983-1984 (Archivo MNCARS).

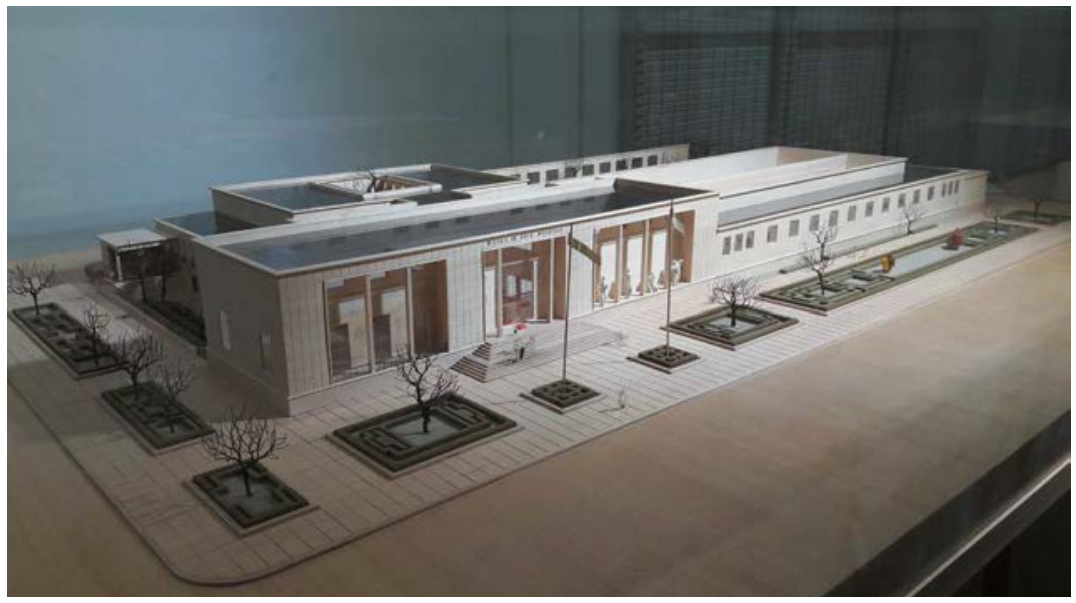

y la síntesis posible entre tradición y modernidad, cuando se refiere a las fachadas del museo: "[...] limitándonos a expresar sobriamente su interior con líneas sencillas y superficies tranquilas, en las que se acusa, a la manera de los edificios clásicos, un módulo, existente también en la planta... Pretendemos que su modernidad sea duradera, habiendo huido por ello de los tópicos de la arquitectura moderna, tan en boga hoy"19. ¿Hay en estas palabras una crítica al formalismo doctrinario de la vanguardia tal como ya habían manifestado otros miembros de la generación del 25 ?.

La apuesta por un lenguaje "ecléctico" convive en el Museo de Arte Moderno con un manifiesto funcionalismo en la distribución del programa, accesos y circulaciones, materializado en un volumen de acusada horizontalidad y rodeado de elementos de transición entre edificio y ciudad, como los jardines de la fachada principal o el patio pergolado de la fachada posterior. En la representación de esta imagen, la esencialidad volumétrica, la estructura modular, y la sinceridad constructiva se alían con el recurso evocador al clasicismo mediterráneo como máscara solemne y ennoblecedora apropiada para edificios públicos y representativos, como constante histórica atemporal después de la polémica del Rincón Goya. El Museo de Mercadal, por otro lado, se integra perfectamente en los ejes por donde discurría el pensamiento arquitectónico internacional en los años veinte y treinta, en que la apuesta clasicista, en su empleo historicista o racionalista, triunfaba respaldada por unas coordenadas ideológicas derivadas de la necesidad de

19 García Mercadal, 1933: 242. García Mercadal, 1934: 48-49. 
incorporar la satisfacción de las necesidades simbólicas consensuadas socialmente, junto a una concepción perdurable de la arquitectura como disciplina artística susceptible de emocionar.

En este punto, en la maqueta del museo, construida en $1984^{20}$, se observan algunas transformaciones respecto al proyecto inicial de los años treinta, en concreto en la fachada de acceso, donde se sustituye la composición asimétrica, la gran cristalera y la marquesina de entrada del proyecto presentado al Concurso de 1933, por una ordenación clásica más conservadora mezclada con motivos vernáculos y racionalistas [figs. 2 a y b]. Se plantea entonces la hipótesis de que hubiera dos versiones del anteproyecto, o, que ahora en los años ochenta del siglo pasado, Mercadal buscase presentar un pensamiento clásico-racionalista más coherente y continuado, lejos de sus imágenes de arquitecto de la vanguardia racionalista.

Esta declinación revela cómo tras la reconocida influencia de arquitectos de vanguardia, afloran en su obra otras variables transmitidas por sus maestros y por arquitectos europeos coetáneos como el alemán Hans Poelzig, quien merece una especial atención en la formación de Mercadal, pues, como Tessenow, fueron desmitificadores del encumbramiento de la técnica, demostrando la compatibilidad entre tradición y modernidad. En la trayectoria de Mercadal posterior a la Guerra Civil la huella de Poelzig se evidencia en ciertas soluciones formales y funcionales de algunos hospitales proyectados entre 1946 y los años setenta para el Instituto Nacional de Previsión, tras su depuración profesional por el régimen franquista ${ }^{21}$.

La labor de Mercadal como arquitecto del Instituto Nacional de Previsión es prolífica y muestra ejemplos de adaptación contextual (también en el sentido ideológico) de gran interés y calidad. En hospitales como la antigua Residencia José Antonio (1947, actual hospital Miguel Servet), apela a una arquitectura "de orden" en ritmos, composición axial, citaciones tipológicas o lexicológicas, las cuales, se fusionan con naturalidad con elementos de tradición racionalista funcionalista ${ }^{22}$. En el Hospital Miguel Servet, Mercadal proyectó dos de los mejores episodios plásticos de su sincretismo lingüístico en los volúmenes semi-exentos de la capilla y el salón de actos, erigidos en cada uno de los patios que flanquean el eje de la entrada principal [figs. $3 \mathrm{a}$ y b].

Tristemente desaparecidos, el salón de actos constituía un volumen cúbico sobre pilotis perforado por pequeños vanos en su parte superior, mientras que la capilla fue concebida como un espacio de planta centralizada con diversas referencias al clasicismo. En este punto cabe recordar la Capilla del Bosque (1918) de E. Gunnar Asplund, construida para el cementerio de Enskede (Estocolmo) también uno de los exponentes de una arquitectura moderna anclada en las raíces tanto de la alta cultura del clasicismo como de la tradición vernácula nórdica. En suma, el Miguel Servet, sin olvidar la adaptación lingüística a las consignas del régimen franquista, constituye una espléndida síntesis moderna-clásico-mediterránea, y un retorno a los orígenes de los años treinta, entroncando con los valores atemporales de la disciplina plasmados en la sobriedad geométrica de las formas del clasicismo mediterráneo.

Esta conciencia de continuidad de su lenguaje está presente en el Suplemento que el propio Mercadal edita en 1972, como reacción al crítico monográfico que le dedica en 1971 Juan Daniel Fullaondo en la revista Nueva Forma ${ }^{23}$. Mercadal reivindica la validez de su biografía arquitectónica al margen de códigos e ideologías, intercalando imágenes de los denostados hospitales y obras de su última etapa con dibujos sobre el Mediterráneo, sugiriendo la inexistencia de una cesura, de un antes y un después, en un acto de afirmación de la unidad de su obra.

\section{La construcción de las analogías mediterráneas de la arquitectura moderna}

Una parte considerable de la producción gráfica y teórica de García Mercadal está relacionada con la difusión de las arquitecturas populares y regionales. En la génesis del funcionalismo

\footnotetext{
${ }^{20}$ Construida bajo la supervisión del arquitecto por Jorge Brunet entre 1983 y 1984, para la exposición que sobre la trayectoria de Mercadal celebró el Museo Español de Arte Contemporáneo de Madrid en 1984.

${ }^{21}$ Layuno, 2011: 74.

22 Fullaondo, 1971: 2-8; 1984. García Mercadal, 1972: 58. Escribano, 2015: 371-381.

23 García Mercadal, 1972.
} 

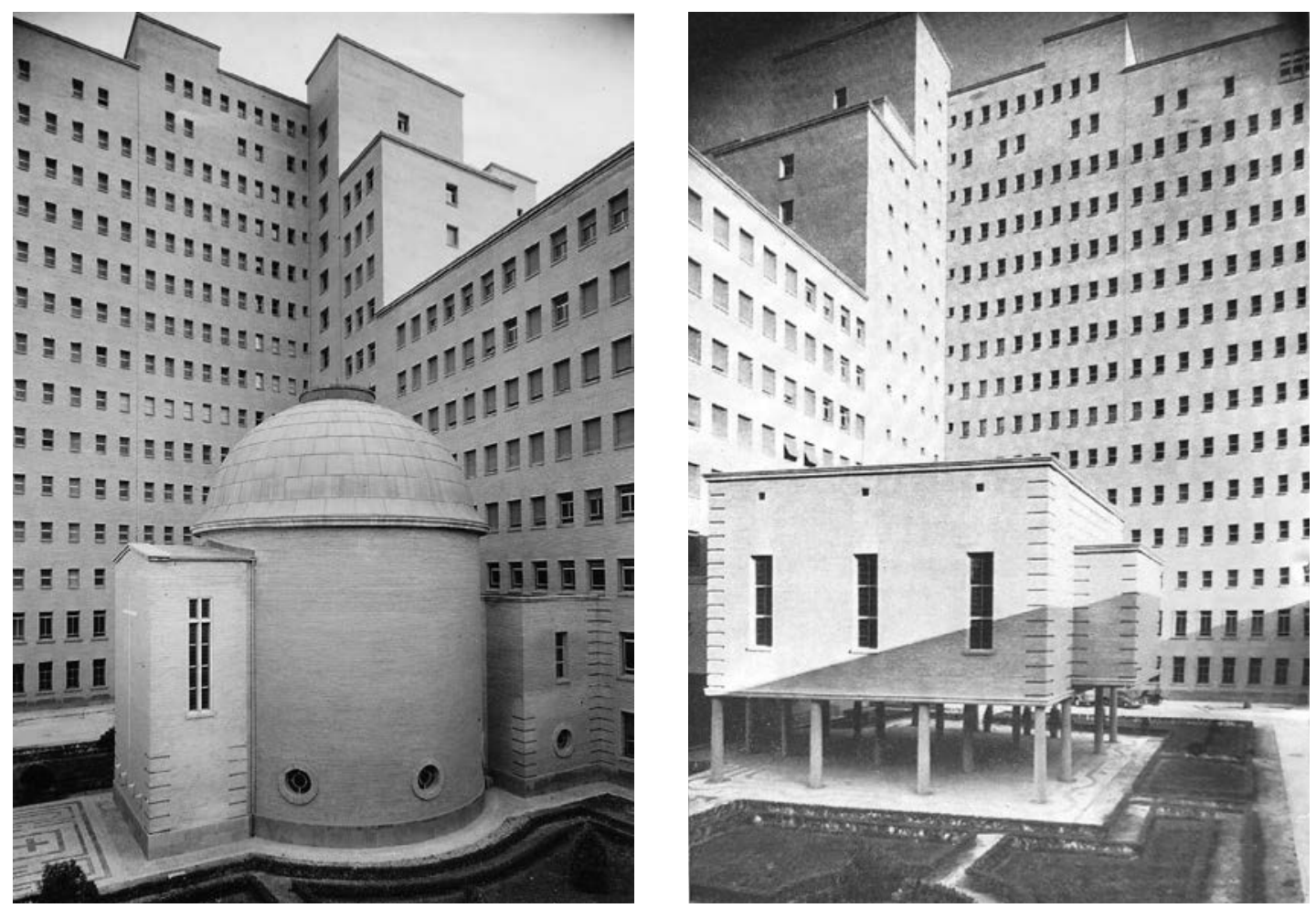

Figs. 3a y 3b. Fernando García Mercadal, Residencia Sanitaria “José Antonio". Zaragoza. 1947. Detalle de la capilla y el salón de actos (destruidos) (1919 FGM 1972. Suplemento Nueva Forma). (Real academia Nacional de Medicina. Bando de imágenes de Medicina Española). http://www.bancodeimagenesmedicina.com/banco-de-imagenes/instituciones-sanitarias/ residencia-sanitaria-de-zaragozaarquitecto-fernando-garcia-mercadal-5688.html).

arquitectónico, la apelación a los modelos primitivos, naturales o vernáculos como depositarios de la sinceridad, la moralidad o la verdad fue una práctica recurrente desde el pensamiento teórico desde la Ilustración, pero con matices. Superando los ideales del clasicismo académico, el término "natural" aparece vinculado al pensamiento historicista y romántico. En los escritos de Pugin una de las aspiraciones de la formación del arquitecto, consistía en el reemplazo del examen de los grandes monumentos por las excursiones al interior del propio país para estudiar la arquitectura tradicional de aldeas, pueblos, y ciudades, pero además, el estudiante:

Debe convertirse en un minucioso observador del mundo animal y vegetal, de las grandes creaciones de la naturaleza. La costa rocosa, el fértil valle, la llanura dilatada, las colinas boscosas, las riberas de los ríos, son todos excelentes temas de trabajo; y los antiguos constructores adaptaron tan bien sus edificios a las distintas localidades, que parecían formar parte de la naturaleza misma como si hubieran brotado de su emplazamiento ${ }^{24}$.

En su ensayo "Clásico y vernáculo", publicado en la revista Architectural Design en 198425, Alan Colquhoun hace arrancar del Romanticismo alemán la dicotomía clásico-romántico. El sistema clásico había situado la arquitectura vernácula en un nivel inferior de la jerarquía de valores disciplinares. Laugier no estaba interesado en el mundo mediterráneo vernáculo real, sino en una destilación de la doctrina clásica, no buscaba el retorno a los primeros días del hombre

${ }^{24}$ A. Pugin, Apología de la resurrección de la arquitectura cristiana en Inglaterra, 1843, cit. por Zurko, 1970: 127.

${ }^{25}$ Colquhoun, 1991: 43-53 
sino a las raíces de la arquitectura clásica. Este proceso implicaba, no el descubrimiento de la construcción vernácula, sino la revernaculización del clasicismo con la que dar sustancia a un mito de los orígenes ${ }^{26}$, próxima a la operación llevada a cabo por el racionalismo moderno.

No obstante, desde finales del siglo XVIII las formas vernáculas comienzan a estudiarse por sí mismas y a ser consideradas no como estilos sino como formas de arte que poseían su significación propia, desafiando las pretensiones universalistas del sistema clásico ${ }^{27}$. Esta bifurcación ideológica clásico-romántica que se haya en los albores de la modernidad, y que llevará a infiltrar ingredientes vernáculos y pintorescos en la alta cultura disciplinar, se anticipa en la obra de Schinkel. Será también la experiencia del viaje (como en Mercadal, Le Corbusier y tantos otros) a la cuna de la civilización clásica, la manera de elaborar una teoría arquitectónica en imágenes que supere una visión puramente académica del trabajo proyectual. A través de la representación gráfica y pictórica del paisaje en su totalidad fenomenológica, se fusionan los elementos monumentales con los naturales, agrarios, productivos y los del hábitat vernáculo. Schinkel viaja a la periferia de la alta cultura arquitectónica, se siente atraído por las arquitecturas rurales de la isla de Capri — como Hoffmann, Le Corbusier, Mercadal...-, reflejando la casa campesina en simbiosis con su entorno natural y cultivado ${ }^{28}$.

El interés de Mercadal por la arquitectura popular del área Mediterránea se inscribe en la estela marcada por generaciones de arquitectos e intelectuales que, desde comienzos del siglo XX en Europa, proponían hallar una solución válida para la innovación de la arquitectura a partir de los recursos ofrecidos por las tradiciones vernáculas, generando una reacción, en primer lugar antiacadémica; y en segundo lugar, antimaquinista, a favor de una alternativa moderna más contextual, humanizada y espiritualizada, como señala la obra de Tessenow en Alemania. Estas investigaciones pronto suscitarían sendos dilemas en el seno del racionalismo entre aspiraciones universalistas y regionalistas.

Junto al decisivo descubrimiento in situ de la arquitectura anónima de las costas del Mediterráneo, los viajes de Mercadal por Europa entre 1923 y 1925 le ponen en contacto con arquitectos como Joseph Hoffmann, cuyos dibujos producto de su viaje a Italia en 1896, publicados en la revista Der Architekt ${ }^{29}$ poseen claros puntos de contacto con los incluidos por García Mercadal en La Casa Mediterránea. En este sentido, un temprano desarrollo del mito de la mediterraneidad en la arquitectura moderna tuvo lugar en la isla de Capri. La isla de hecho fue una fuente de inspiración para las teorías estéticas que buscaban un equilibrio entre clasicismo y modernidad, difundidas entre otras por la revista Valori Plastici, editada en Roma entre 1918 y $1922^{30}$. Capri, por su conjunto urbano y paisajístico se constituyó en los años veinte del siglo pasado en el epicentro de un debate sobre el lenguaje de la arquitectura moderna de inspiración vernácula y sobre el propio devenir patrimonial de la arquitectura y el paisaje rurales. El proyecto de reconstrucción de la Casa di Tragara aprovechando una vivienda preexistente había desatado por entonces una intensa polémica disciplinar motivada por el empleo de técnicas constructivas modernas en la arquitectura de la isla. Este tema fue precisamente abordado en el Primer Convegno del Paesaggio celebrado en Capri en julio de 1922, promovido por el arquitecto Edwin Cerio, alcalde de la isla entre 1920 y $1923^{31}$, y en el que se enfrentaron posturas a favor y en contra de los logros técnicos de la nueva arquitectura, poniendo de relieve la preocupación por la protección y conservación del paisaje, los valores de la arquitectura rural y las costumbres de la isla ${ }^{32}$.

Un debate al que no sería ajeno Mercadal, quien, aún sin participar personalmente en el Congreso, sin duda tuvo acceso a las Actas del mismo, probablemente en el transcurso de su viaje a Capri en 1924 durante su estancia en Roma. Lo cierto es que las contribuciones del Congreso,

${ }^{26}$ Colquhoun, 1991: 53

27 Colquhoun, 1991: 45

28 Semerani, 1982: 19.

${ }^{29}$ Gresleri, 1983: 24; García Mercadal, 1982: 50.

30 Ponzi, 2008: 105-106.

31 Mangone, Belli, Tampieri, 2015: 237-255.

32 Cerio, 1923. Cohen, 2013: 126 


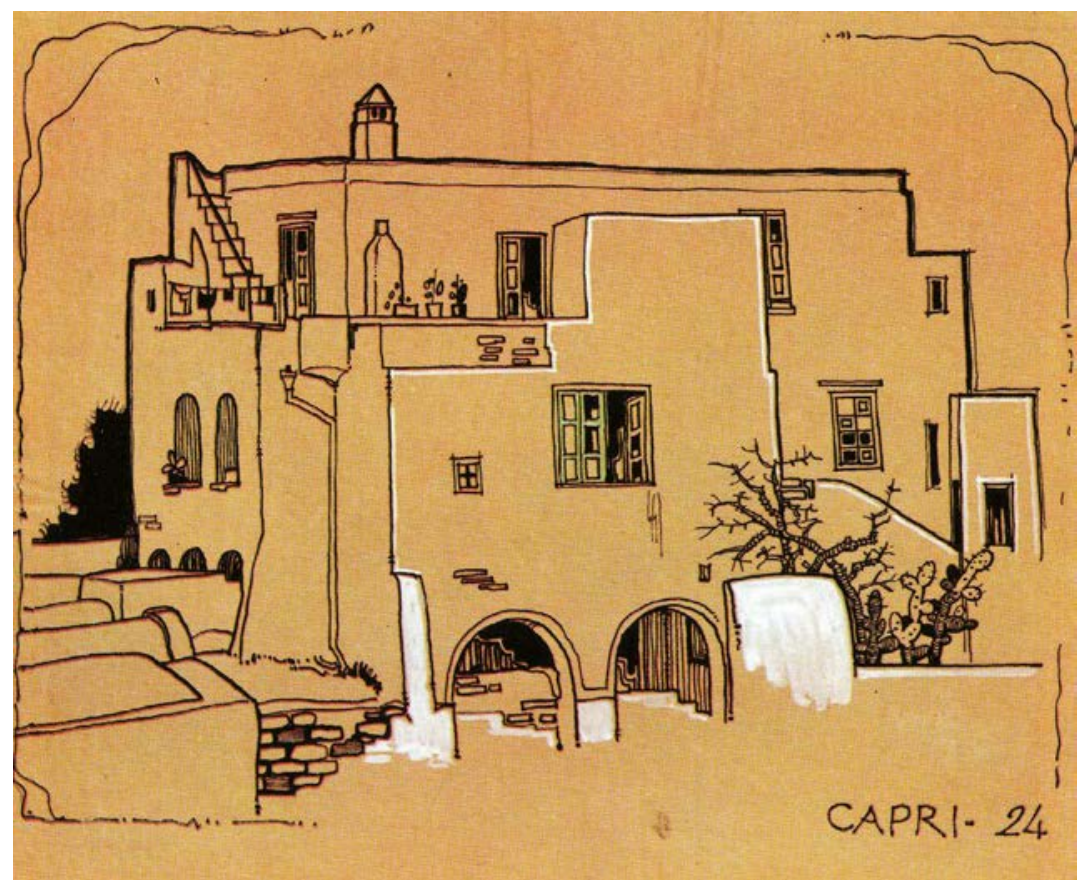

Figs. 4a y 4b. Fernando García Mercadal, Casa en Capri. 1924. Dibujo (La Casa Mediterránea, 1984) y Casa en Anacapri

(Fuente: Convegno del Paesaggio, Capri, 1923).

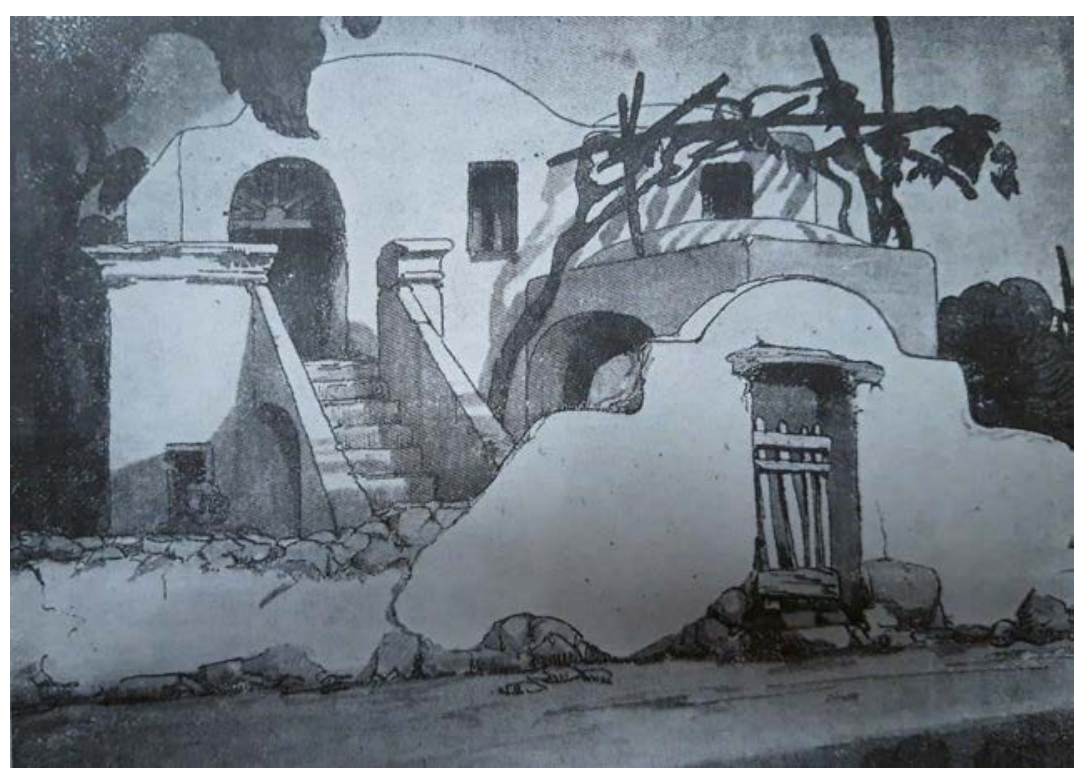

aparecen en textos como Camino de Grecia. Notas del primer viaje (Febrero 1924) (1980) 33 ; y en los contenidos y dibujos sobre la arquitectura de Capri incluidos en La Casa Mediterránea ${ }^{34}$, editado con motivo de la retrospectiva sobre Mercadal celebrada en el MEAC en $1984^{35}$ [fig. 4 a y b].

33 García Mercadal, 1980a. Los inicios de su interés por el Mediterráneo y su arquitectura proceden de antes de su pensión cuando visita Italia en 1921. Mercadal viaja entre 1924 y 1925 desde Roma a Nápoles, Capri, la costa Amalfitana, Sicilia, llegando al Peloponeso, Atenas, y a Estambul, un viaje a la cuna del clasicismo greco-romano.

34 García Mercadal, 1984b: 15.

35 García Mercadal, 1984a: 18. Véase García Mercadal, 1980b: 89-94. 
Esta doble dimensión de inspiración proyectual y consideración patrimonial de la arquitectura vernácula sería a su vez absorbida por Mercadal en Roma a través de los estudios que divulgó la revista Architettura e Arti Decorative ${ }^{36}$. En ella, arquitectos como Plinio Marconi, Marcelo Piacentini o Roberto Pane escribían sobre el valor intrínseco de la arquitectura vernácula como fuente de lecciones y de innovación, o sobre el carácter plástico, cromático y volumétrico de estos conjuntos ${ }^{37}$. Estos artículos también clamaban contra la desaparición masiva de las construcciones populares, coincidiendo con el tono que aparece en los textos posteriores de Mercadal en defensa de las arquitecturas populares ${ }^{38}$.

En la práctica, los envíos de su labor de pensionado en Roma materializan testimonios de su investigación a favor de elaborar un código lingüístico moderno apoyado en las lecciones del contexto arquitectónico clásico-mediterráneo. Resulta significativo en este sentido, que los tres ejercicios que realiza Mercadal como parte de sus obligaciones académicas entre 1924 y 1926 constituyan trabajos de arquitectura residencial (Arquitectura menor en Roma ${ }^{39}$, Restauración de la Casa del Fauno en Pompeya ${ }^{40}$, La vivienda en Europa), y que en ellos se incluyan memorias, dibujos, planos, fotografías y maquetas sobre la Casa Mediterránea.

Mercadal también divulgó estos estudios sobre la elaboración de un hábitat mediterráneo moderno en los dos conocidos artículos que llevan por título "Arquitectura Mediterránea", publicados en la revista Arquitectura en 1926 y 1927. En el primero, Mercadal intenta demostrar "[...] que existe fundamento para poder hablar de una Arquitectura mediterránea"41, empleando una argumentación no disciplinar sino inspirada en las teorías de la geografía humana de Albert Demangeon, sin duda debido al rigor científico con que se estaba analizando el tema del hábitat rural desde la geografía humana, a través de sus valores físicos, sociales, económicos y sus formas de agrupación. El hábitat constituye para el arquitecto aragonés un hecho cultural, geográfico e histórico, no abstracto ni mecanizado. Su consideración de la vivienda campesina como producto del suelo y de la geografía, y de los usos agrícolas parece contradecir cualquier premisa de abstracción de origen tecnológico, fortaleciendo el apego al lugar por encima de la universalidad de soluciones ${ }^{42}$.

Por su parte, los proyectos que ilustran el artículo del año 1926 pertenecen a los estudios romanos sobre la Casa Mediterránea, y ni se corresponden con el discurso textual, ni son objeto de análisis descriptivo. Como muestran las imágenes, se trata esencialmente de variaciones formales a partir de la paulatina depuración racionalista de las formas del clasicismo y del vernáculo, mezclados con temas y técnicas del racionalismo moderno. Mientras que los alzados para la "casa en Sicilia" y el hotel para viajeros en Palermo reflejan la influencia de su estudio de las arquitecturas menores de Roma, y la contaminación de sus dibujos del viaje al Golfo de Nápoles, Capri y Sicilia ${ }^{43}$; el chalet a la orilla del mar plantea un estudio tipológico de gran interés, pues define una estructura de casapatio, cuya composición en L abraza un espacio interior cerrado en dos de sus lados por una pérgola, que, a modo de pantalla permeable, comunica la casa con el exterior [fig. 5], anticipando algunas soluciones del anteproyecto de Museo de Arte Moderno para Madrid (1933).

${ }^{36}$ Editada en Roma y Milán. La revista era el órgano del Sindicato Nazionale di Architetti. Mangone, 2015: 250-51.

37 Pane, R. (1928): "Tipi di architettura rustica in Napoli e nei campi Flegrei", en Architettura e arti decorative, n. ${ }^{\circ}$ 12, pp. 529-543; Marconi, Paolo (1929): “Architettura minime mediterranee e Architettura moderna", en Architettura e arti decorative, I, settembre; Piacentini, Marcelo (1922): Recensione a Cerio, E. "La casa nel paesaggio di Capri”, en Architettura e arti decorative, marzo-aprile, p. 595; Gerola, G. (1929): "Architettura minore e rustica trentina", en Architettura e Arte Decorative, anno VII, vol. 2, pp. 291-301; Cipriani, G (1927): "Motivi d'architettura ischiana", en Architettura e Arte Decorative, anno VI, vol. 2, pp. 481-494.

38 García Mercadal, 1982: 45-55.

39 Archivo RABASF, sig. 57-2/5. Díez Ibargoitia, 2015: 346-349. García Mercadal, 1926: 293-294.

40 García Mercadal, 1926b: 100-106. Mercadal realizó una serie de modelos sobre la Casa Mediterránea, con sus correspondientes maquetas, planos y fotografías. Estas últimas se han consultado en el Archivo de la Rabasf. Caja 28sign. 2706-2719.

41 García Mercadal, 1926a: 192-197. cita en p. 197.

42 García Mercadal, 1984b. García Mercadal, 1984a.

${ }^{43}$ Hernández, 2017: 282-283. 
Fig. 5. Fernando García Mercadal, Estudios sobre la Casa Mediterránea. Chalet a la orilla del mar. Maqueta (Arquitectura, n. ${ }^{\circ} 85,1926$ ).

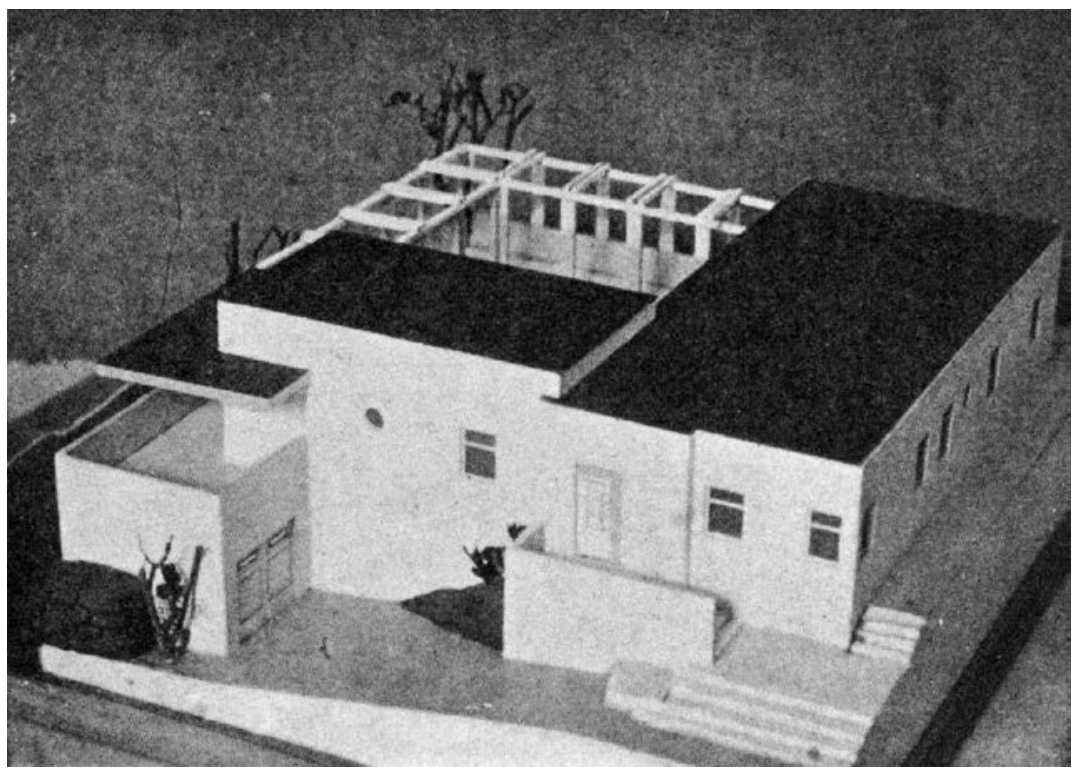

La proliferación de cubiertas planas y transitables, volúmenes cúbicos y escalonados, superficies lisas, asimetrías, marquesinas, patios, pérgolas, terrazas y pequeños jardines tapiados, abiertos hacia el exterior y el paisaje, conectan a Mercadal con las lecciones de la modernidad europea y las funde con las tradiciones clásico-mediterráneas, dando forma a una arquitectura residencial burguesa, estrechamente vinculada tanto a la arquitectura de compromiso de la generación del $25^{44}$, como a la arquitectura del clasicismo moderno europeo.

Al año siguiente Mercadal publica un segundo artículo con el título "Arquitectura Mediterránea"45, en el que, ahora sí, intensifica la iconografía de la modernidad en el Anteproyecto de Club Náutico para una ciudad mediterránea, tratándose también de un ejercicio de pensionado elaborado en otoño de 1925. Con sus metáforas navales alusivas a la cultura del ocio burgués [fig. 6], este anteproyecto, como ya se ha comentado, fue pionero en la introducción en la arquitectura española de la estética maquinista del racionalismo funcionalista de inspiración lecorbusiana.

Resulta interesante la comparativa de este trabajo con el realizado en el mismo año por el también pensionado y amigo de Mercadal, el arquitecto Emilio Moya Lledós, con el tema aeropuerto para aeroplanos e hidroplanos con estación ferroviaria y gran plaza de acceso. La solución formal empleada en este último contrasta con la apuesta de Mercadal, pues Moya, a pesar del futurismo del tema, fusiona en una estructura formas y elementos clásicos (pórticos y exedras tratadas de manera abstracta, referencias a la cúpula del Panteón romano), de la que emergen dos torres de rascacielos con cubierta a doble vertiente. Un tema de vanguardia anclado en un lenguaje que se resiste a abandonar el código clásico. La lección de Roma está muy presente ${ }^{46}$. Por su parte, el anteproyecto de Mercadal prefigura el edificio que se convertirá en un hito del Gatepac y de la arquitectura racionalista española, el Club náutico de San Sebastián de los arquitectos Aizpurúa y Labayen (1928-1929) ${ }^{47}$.

A este anteproyecto, Mercadal acompaña en el artículo citado la propuesta para la Casa del ingeniero D. Álvaro Bielza [figs. 7 a y b]. De sus imágenes, resulta interesante la sección de la casa pues muestra un sistema constructivo mixto, estructuras de hormigón armado junto a bovedillas tabicadas en el forjado del techo que cubre el hall a triple altura, como guiño al vernáculo,

44 Díez Ibargoitia, 2015: 343.

45 García Mercadal, 1927: 190-193.

46 Archivo Real Academia de España en Roma. Comunicaciones Oficiales. Carpeta III-54. Esteban, 2003: 126.

${ }^{47}$ Laborda, 2008: LII-LIII. 


\section{A R Q U I E C T URA MEDITERRA NEA \\ Por F. GARCIA MERCADAL}

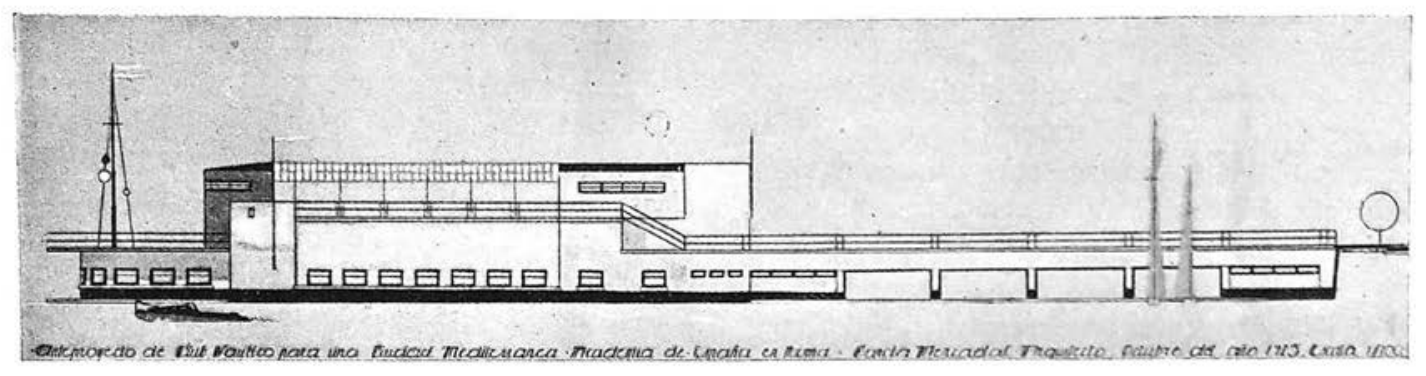

Glub Náutico. Fachadi princtipal.

Arq. Garcia Mercadal.

La horizontalidad predominante, ia simplicidad de las formas-nacidas de su estructura-, la ausencia absoluta de decoración y una ligeya intervención del color son algunas de las pretendidas características. La cabina será roja, el lo, que disimulará las huellas de las pequeñas variaciones de nivel, debido a las mareas.

El programa es bastante limitado: cios plantas bastan para alojar todas las dependencias y servicios. Como elemento esencial, en planta baja, la

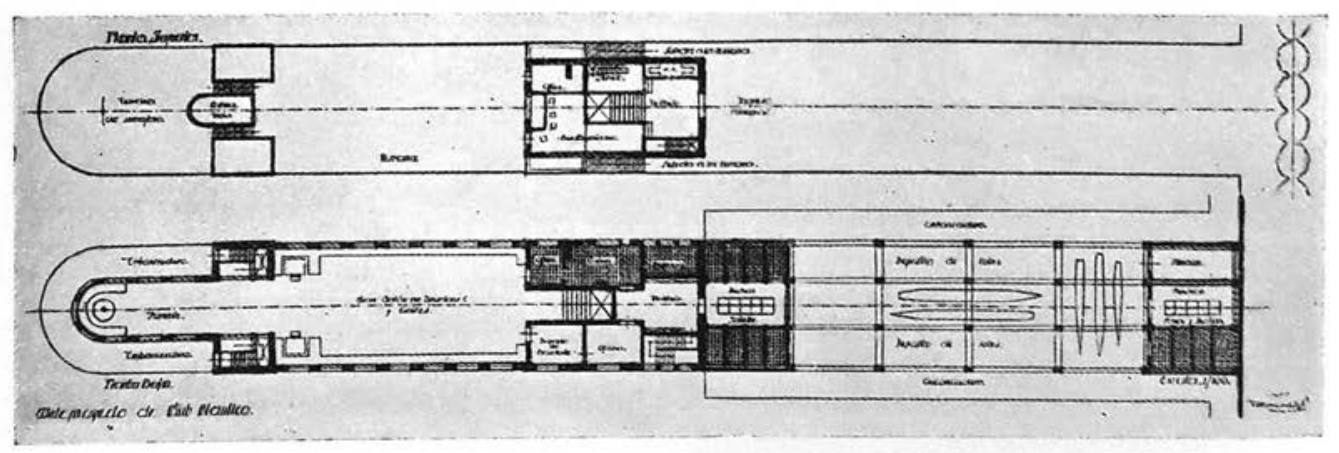

Club Náutico. Plantas.

Arq. García Mercadal.

resto del edificio, blanco, a excepción de una faja negra (alquitrán y brea) a manera de zóca. sala de fiestas, que servirá también de juntas, de lectura..., un "fumoir", un despacho para el pre-

\section{I9O}

Fig. 6. Portada del número 97 de la revista Arquitectura (1927) dedicado a la "Arquitectura Mediterránea", con el anteproyecto de Club Náutico.

empleado también por arquitectos como Le Corbusier o Josep Lluís Sert ${ }^{48}$. Y es que no sólo las analogías formales del geometrismo desornamentado de la arquitectura popular formaban parte del debate de la época, sino también la consideración de las cuestiones de orden técnico-constructivo resultaban imprescindibles en el abordaje de una arquitectura moderna derivada de las lecciones de lo popular. Si Mercadal pasa por alto profundizar en este debate teórico, que, como

48 Hernando de la Cuerda, 2016: 141-146. 

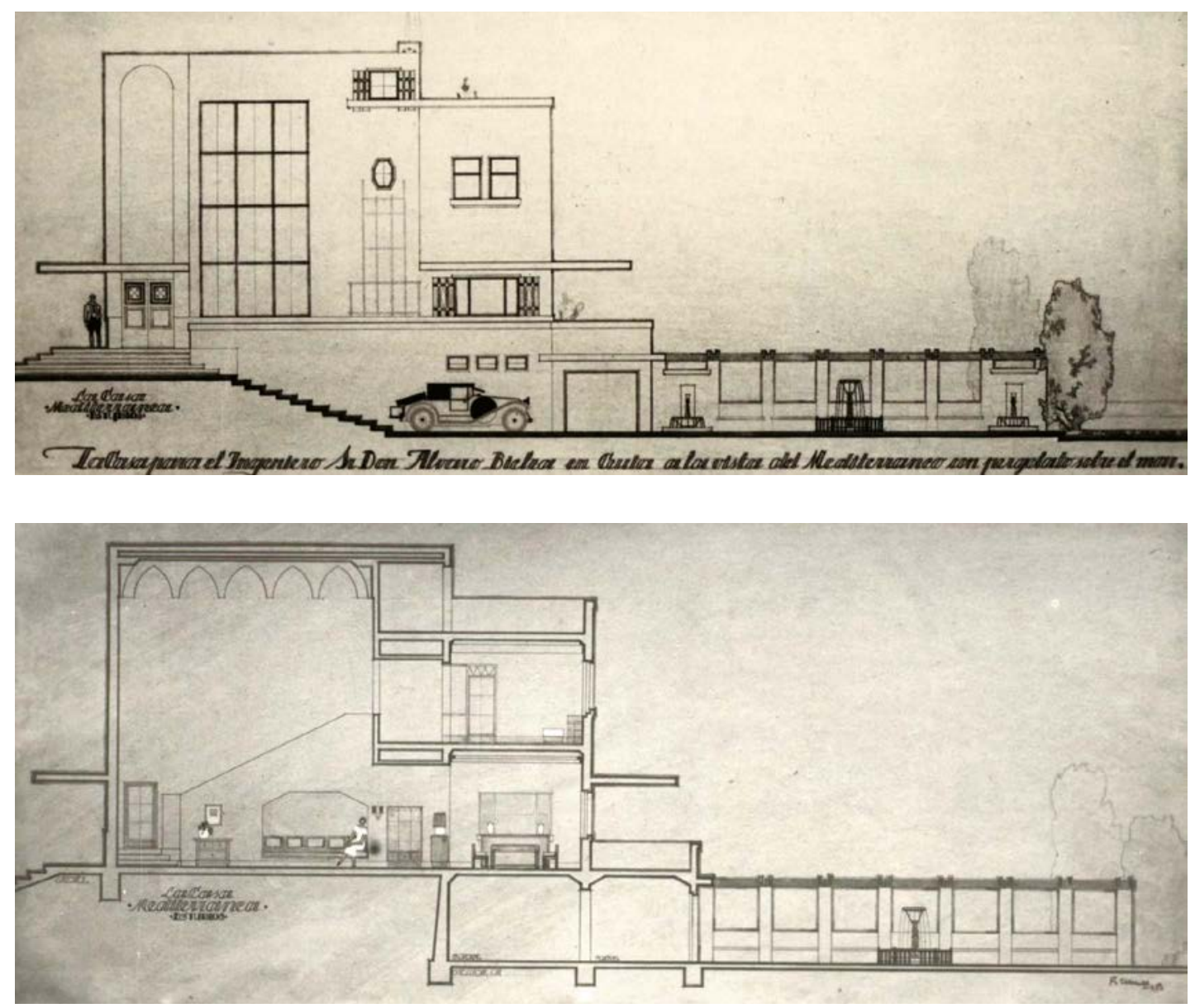

Figs. 7a y 7b. Fernando García Mercadal, Casa para el ingeniero D. Álvaro Bielza. Ceuta. 1925. Alzado y sección longitudinal. (Archivo RABASF: Fondo Fernando García Mercadal. Fotos 2714, 2715, 2716).

se ha mencionado, centró parte de las intervenciones del Convegno del Paesaggio celebrado en Capri en 1922, la polémica sobre la legitimidad de incorporar a las lecciones formales del vernáculo las técnicas constructivas modernas sería planteada por Le Corbusier en un ensayo publicado en 1937 en la revista Domus bajo el título "Il "vero" sola ragione dell'architettura"49, donde el maestro suizo se posicionaba en defensa del uso de las nuevas técnicas, aunándolas con la claridad formal de la arquitectura popular ${ }^{50}$.

En síntesis, bajo la influencia de Adolf Loos o Le Corbusier, estos proyectos de Mercadal, que explotan el predominio de la forma sobre cualquier otra condición, en su condición de imágenes de modernidad, reflejan un cambio de referentes hacia los centros de la vanguardia centroeuropea, con el objetivo decidido de elaborar una propuesta lingüística que oscilara hacia la estética de la arquitectura del funcionalismo racionalista sin perder las raíces contextuales vernáculas.

Esta afirmación posee otro correlato en la propuesta residencial contenida en la Memoria Estudio sobre la vivienda europea $(1926)^{51}$, un envío de pensionado que discurre en estrecha

${ }^{49}$ Le Corbusier: "Il "vero" sola ragione dell'architettura", en Domus, n. ${ }^{\circ} 118$, oct. 1937, pp. 1-8. Cohen: 2013: 123-128.

50 Talamona, 2004: 184-193. Gravagnuolo, 1997: 107-114.

51 García Mercadal, 1998. El texto resume los conocimientos de Mercadal sobre la arquitectura residencial más innovadora, desde las teorías del funcionalismo racionalista, especialmente el maquinismo y la estandarización de la 
Fig. 8. Fernando García Mercadal, Proyecto de casas baratas en Sevilla. 1930. Perspectiva (Arquitectura, 142, 1931).

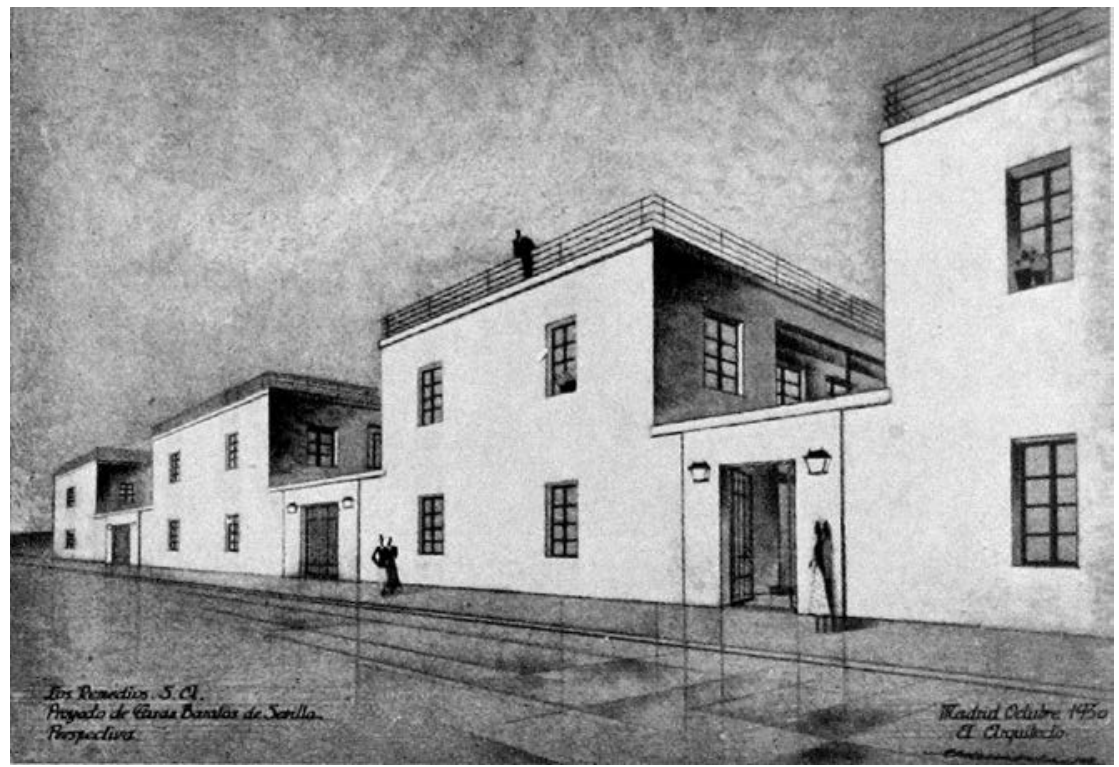

vinculación con la línea de trabajo de los artículos publicados en la revista Arquitectura. La lección internacional ofrecida por las experiencias de innovación residencial holandesas, alemanas y francesas que aparece en la Memoria de Mercadal, derivará hacia una propuesta personal de carácter "contextual", y vinculada como no podía ser de otro modo, a sus investigaciones sobre la arquitectura residencial mediterránea. En el escrito Algunos tipos para una ciudad jardín mediterránea ${ }^{52}$, realiza los siguientes comentarios:

Supondremos la ciudad a las orillas del Mediterráneo y en las proximidades de una gran ciudad que no sea un centro industrial, ya que nuestros tipos fueron planteados más bien para ser habitados por familias pertenecientes a la clase media y baja burguesía, no por obreros. Gentes ocupadas en un trabajo más bien intelectual, gentes que sienten el deseo de una vida sana e higiénica en un ambiente grato, que sienta el gusto por las flores y el campo, pero que no tienen ni condiciones para cultivar por sí solos un huerto o jardín, ni tampoco medios económicos que le permitan disponer de un jardinero $[\ldots]^{53}$

Con esta declaración, Mercadal, reconduce las teorías sobre la construcción en serie de la vivienda obrera, que constituía el ámbito más experimental de las aportaciones europeas, hacia una propuesta de suburbio burgués con siete tipos de viviendas de las que describe la distribución funcional pero no los aspectos constructivos, y apenas los formales. La fusión de los principios del urbanismo higienista y de la tipificación residencial y modernización del hábitat burgués para clases intelectuales y liberales expresada en el texto se inspiraba claramente en los conceptos del propio Le Corbusier en su "Manual de la Habitación"54.

Las propuestas y estudios descritos forman parte de los eslabones de una cadena de elaboración teórica y proyectual sobre la mediterraneidad por parte de Mercadal, desarrollada básicamente entre 1923 y 1927, que parte de los estudios de la casa mediterránea publicados en los artículos de Arquitectura para concretarse en sus primeras obras construidas, el Rincón Goya

casa como máquina habitable contenidos en el Vers une Architecture de Le Corbusier, hasta las experiencias holandesas, pasando por el prototipo Haus am Horn elaborado en la Bauhaus en 1923.

52 García Mercadal, 1998: 107-110.

53 García Mercadal, 1998: 108.

${ }^{54}$ García Mercadal, 1998: 108. 
(Zaragoza, 1926-1928), Villa Amparo (Mallorca, 1927), y las casas para el Dr. Horno (1929) y el pintor Díaz Caneja (1931), en Zaragoza y Madrid. No obstante, estos resultados no parten o desembocan en una investigación constructiva y funcional de posibles prototipos estandarizados de vivienda mínima, sino que a la postre muestran unas coordenadas formales de producción de edificios singulares de hábitat para una élite intelectual o acomodada, compartidas por otros arquitectos de su generación a los que admira, como Loos o Le Corbusier.

Por el contrario, cabe destacar por su carácter excepcional el conjunto residencial de vivienda social Casas baratas en Sevilla (1931), proyectado por Mercadal para la cooperativa Los Remedios [fig. 8], en este caso planteando fórmulas de renovación basadas en la casa patio popular del barrio de Triana con corredor abierto hacia el interior, en las que trató de conservar "[...] el carácter tradicional de las viviendas modestas, modernizándolas e higienizándolas de modo que reúnan las condiciones mínimas exigidas hoy a las casas del proletariado"55. Ahora es cuando Mercadal condensa con claridad tanto los rigurosos estudios tipológicos sobre la vivienda rural que desde los primeros decenios del siglo habían llevado a cabo algunos arquitectos españoles, ideando fórmulas innovadoras aplicables a la estandarización moderna para viviendas de la clase obrera ${ }^{56}$, como los estándares aprendidos en sus viajes centroeuropeos.

Precisamente estas viviendas sociales alcanzan la condición moderna a partir de una abstracción del vernáculo, motivada precisamente por necesidades de economía de medios y ausencia de decoración, no observable en otras obras y proyectos, tanto del propio Mercadal como de otros arquitectos de su tiempo, circunstancia ya señalada por la crítica al denunciar la instrumentalización formalista de la arquitectura mediterránea: "[...] una arquitectura académico-popular, artificiosa, por parte de arquitectos "documentados", que abusan de pérgolas, solanas, porches, que deforman su verdadero sentido" ${ }^{57}$. Estas afirmaciones recogidas en la revista Ac/Gatepac en 1935 entroncan con las reflexiones que en torno a las contaminaciones figurativas de lo vernáculo plantearon críticos como José Moreno Villa, quien argumentaba con agudeza la posible artificiosidad de las concomitancias entre arquitectura popular y arquitectura moderna a partir de la manipulación de imágenes y conceptos, y, ahondando en la idea de purismo, claridad y limpieza como cualidades de la arquitectura, afirmaba que el "estilo" es sinónimo de lujo y que la "pobreza" - por necesidad - de la arquitectura popular es lo que determina su ausencia de ornamento, no su voluntad de estilo. Por el contrario, en la arquitectura moderna la "limpieza", aunque nacía también de un problema económico, era ante todo un asunto "consciente", estético de la nueva arquitectura $^{58}$.

Las elaboraciones de Mercadal anticiparon y cimentaron el discurso en torno a la arquitectura mediterránea como génesis de la modernidad que acompañó a la expansión del racionalismo funcionalista en Europa, desembocando en la construcción de una teoría mediterránea de la arquitectura moderna en los países del sur, como España o Italia ${ }^{59}$, la cual constituiría uno de los objetivos básicos del programa del Gatepac.

El argumento de la génesis mediterránea de la arquitectura moderna, sería retomado por Mercadal en 1980 en su Discurso de Ingreso a la Academia de San Fernando, Sobre el Mediterráneo, sus litorales, pueblos, culturas (imágenes y recuerdos) ${ }^{60}$. Mercadal ahora ofrecía una visión retrospectiva, quizás con un tono de escasa profundidad dialéctica desde el punto de vista disciplinar ${ }^{61}$, de la vinculación entre arquitectura popular mediterránea y arquitectura moderna, recordando que llegó a estas conclusiones durante sus estancias en París, Viena y Berlín entre 1924 y 1927, cuando observó que la arquitectura que se enseñaba entonces se parecía a las cons-

55 García Mercadal, 1931a: 48-50.

56 Sambricio, 2004: 49-84.

57 García Quiñones, 2005: 915 (publicado en la editorial de AC, n. ${ }^{\circ}$ 18, segundo trimestre de 1935, p. 15. Este número estaba dedicado a La arquitectura popular mediterránea)

58 Moreno Villa, 1931: 187-193.

59 Bohigas, 1978: 15-28. Rovira, 2003: 128-135. Pizza, 1997.

${ }^{60}$ García Mercadal, 1980b

61 Pozo Municio, 2010: 63-71. 
trucciones populares por sus cubiertas con terrazas, su ausencia de decoración, así como por el elemental funcionalismo. Y subrayando las raíces universales de la modernidad afirma: "Estas arquitecturas populares mediterráneas, de sus islas y sus litorales, datan de varios siglos antes del "cubismo" arquitectónico de las modernas tendencias de 1923" $"$.

\section{Conclusiones}

El carácter de la trayectoria de García Mercadal planteaba lo que algunos críticos de su época como Ernesto Giménez Caballero calificaban ya por entonces como "un problema desasosegador y de muchas dimensiones" 63 , instancia que ha abierto la posibilidad de realizar otras lecturas críticas yuxtapuestas a la "historia selectiva" de su compromiso con la modernidad. Lecturas en las que referentes alternativos, otros contactos e intereses permiten construir un esquema caleidoscópico de su personalidad, hacia interpretaciones que se enfrentan a la valoración inicial bastante unilateral de su figura, en la que aquellos procesos que no encajaban con el discurso ortodoxo fueron marginados, a lo que sumar la desaparición, transformación, o no ejecución de proyectos imprescindibles para hacer una justa apreciación de su producción. El clasicismo, por un lado, y el regionalismo y vernáculo mediterráneo, por otro, representan en su pensamiento la posibilidad de encontrar una modernidad determinada por el medio o la tradición disciplinar. Las imágenes sobre el clasicismo o el vernáculo afloran en sus aportaciones gráficas y teóricas, y se infiltran en sus proyectos de manera fragmentada, pero revelan en su conjunto una continuidad de intereses. Esta mentalidad conciliadora con la tradición nos enfrenta a su vez a un Mercadal que comprende que, aun asumiendo las innovaciones vanguardistas, la arquitectura al fin y al cabo no puede ser un ejercicio completamente abstracto, sino que su propia concreción tiene que ver con el sentido del contexto en su acepción más amplia.

La historiografía se ha enfrentado con dificultad también a esta renuncia de la imagen del Mercadal racionalista, sobre todo porque no existen explícitas manifestaciones del arquitecto que remitan a una postura ideológica clara de rechazo a la opción de vanguardia, como por ejemplo sí existieron en otros arquitectos como Luis Lacasa. Mercadal no hace explícitos estos juicios críticos, sino que tiende puentes hacia una arquitectura de fusión personal.

La continuidad de algunos de estos principios proyectuales antes y después de la Guerra Civil apartan a Mercadal de las nuevas tendencias que se adscribieron al organicismo y a otros lenguajes en los años cincuenta, y, por tanto, lo sitúan al margen del relato de la historiografía de la Historia de la Arquitectura Contemporánea española, hasta que su figura comienza a ser revisada por la crítica a finales de la década de los 70 del siglo pasado, abriendo nuevas relecturas de su trayectoria silenciada.

\section{BIBLIOGRAFÍA}

Anasagasti, Teodoro de (1918): "La tradición, el plagio y el pastiche nos envenenan”. En: la construcción moderna, 15. Cerio, Edwin (1923): Convegno del Paesaggio. Capri: pagine dell’Isola, Nápoles: G. Casella.

Cohen, Jean-Louis (ed.) (2013): Le Corbusier. An atlas of the modern landscapes. Nueva York: Thames and Hudson. Colquhoun, Alan (1991): Modernidad y tradición clásica. Madrid: Júcar Universidad.

Díez Ibargoitia, María (2015): La lección de Roma para los arquitectos de la Academia de España: 1904-1940. Madrid: Aecid.

Escribano Marquina, Jesús (2015): “Arquitectura hospitalaria del Instituto Nacional de Previsión en Aragón. El hospital Miguel Servet de Fernando García Mercadal”. En: Layuno, A., Acosta, A., Echeverría, E. (coords): Patrimonio, territorio y paisaje. Jornadas internacionales de investigación. Alcalá de Henares: Servicio de publicaciones de la Universidad (CDrom), pp. 371-381.

62 García Mercadal, 1980: 38.

63 Giménez Caballero, 1928. 
Escribano Marquina, Jesús (2017): Arquitectura hospitalaria del Instituto Nacional de Previsión en Aragón. El hospital Miguel Servet de Fernando García Mercadal. [Tesis doctoral inédita]. Universidad de Alcalá.

Esteban Chapapría, Julián (2003): "Emilio Moya Lledós. Arquitecto conservador de monumentos (1929-1936)". En: Roma y la tradición de lo nuevo. Diez artistas en el Gianicolo (1923-1927). Madrid: Sociedad Estatal para la Acción Cultural Exterior, pp. 118-129.

Flores, Carlos (1989): Arquitectura española contemporánea. Madrid: Aguilar (2 vols).

Fullaondo, Juan Daniel (1971): "Fernando García Mercadal: elegía y manifiesto". En: monográfico Nueva Forma, 69.

Fullaondo, Juan Daniel (1984): Fernando García Mercadal. Arquitecto aproximativo, Madrid: C.O.A.M.

García Mercadal, Fernando (1924): "Del clásico, de su enseñanza y sus relaciones con la arquitectura moderna". En: Arquitectura, 60, Madrid, pp. 150-152.

García Mercadal, Fernando (1926): "La arquitectura menor en Roma”. En: Arquitectura, 86, pp. 293-294.

García Mercadal, Fernando (1926a): “Arquitectura mediterránea”. En: Arquitectura, 85, pp. 192-197.

García Mercadal, Fernando (1926b): "Envío de los pensionados en Roma. La casa del Fauno-Pompeya". En: Arquitectura, 83, pp. 100-106.

García Mercadal, Fernando (1927): “Arquitectura mediterránea”. En: Arquitectura, 97, pp. 190-193.

García Mercadal, Fernando (1931a): "Casas baratas en Sevilla”. En: Arquitectura, 142, pp. 48-50.

García Mercadal, Fernando (1933): "IV concurso nacional de arquitectura. Tema: un museo de arte moderno en Madrid". En: Arquitectura, 173, pp. 241-247.

García Mercadal, Fernando / Rivas Eulate, José María (1934): "Chalet del Puerto de Navacerrada de los arquitectos Fernando García Mercadal y José María Rivas Eulate”. En: Arquitectura, 3, pp. 83-90.

García Mercadal, Fernando (1972): 1919 FGM 1972, (suplemento con tirada limitada al núm. 69 de Nueva Forma).

García Mercadal, Fernando (1980a): "Camino de Grecia. Notas del primer viaje (Febrero 1924)". Boletín de la Real Academia de Bellas Artes de San Fernando. Separata Academia. 51, Madrid.

García Mercadal, Fernando (1980b): Sobre el mediterráneo, sus litorales, pueblos, culturas: imágenes y recuerdos. Discurso de ingreso en la Real Academia de Bellas Artes de San Fernando el 20 de Abril de 1980. Madrid: Real Academia de Bellas Artes de San Fernando (sig. dis-289).

García Mercadal, Fernando (1981): La casa popular en España (prólogo de A. Bonet Correa). Barcelona: Gustavo Gili, 1981. Publicada inicialmente por Espasa-Calpe en 1930.

García Mercadal, Fernando (1982): "Defensa y protección de la arquitectura popular mediterránea". En: AA.VV., defensa, protección y mejora del patrimonio histórico-artístico y arquitectónico. Madrid: Colegio Oficial de Arquitectos de Madrid, 1982, pp. 45-55.

García Mercadal, Fernando (1984a): Arquitecturas regionales españolas. Madrid: Comunidad de Madrid. Consejería de Cultura, Deportes y Turismo. Dirección General de Cultura.

García Mercadal Fernando (1984b): La Casa Mediterránea: Fernando García Mercadal. Madrid: Ministerio de Cultura. Dirección General de Bellas Artes y Archivos.

García Mercadal, Fernando (1998): La vivienda en Europa y otras cuestiones (con introducción de Paloma Barreiro), Zaragoza: Institución Fernando el Católico, (CSIC) Diputación de Zaragoza.

García Quiñones, Belén (coord.) (2005): AC. publicación del Gatepac. Barcelona: Fundación Caja de Arquitectos.

Giménez Caballero, Ernesto (1928): "Fernando García Mercadal", nuevo arte en el mundo. "Arquitectura, 1928". En: la Gaceta Literaria, 32, 15 de Abril.

Gravagnuolo, Benedetto (a cura di) (1997): Le Corbusier e L'Antico. Viaggi nel Mediterraneo. Nápoles: Electa.

Gresleri, Giuliano (1983): Josef Hoffmann, Barcelona: Gustavo Gili.

Guerrero, Salvador (2008): "Fernando García Mercadal o la vanguardia imposible". En: A.C., La Revista del G.A.T.E.P.A.C. 1931-1937. Madrid: Museo Nacional Centro de Arte Reina Sofía, pp. 48-51.

Hernández Martínez, Ascensión (2017): “Alla Scoperta dell'Architettura Vernacolare Mediterranea: Il Viaggio dell'architetto spagnolo Fernando Garcia Mercadal in Sicilia (1924)”. En: La Sicilia nello sguardo degli altri: architetti in Viaggio. Catania: Lettera Ventidue, pp. 271-287.

Hernando de la Cuerda, Rafael (2016): Fernando García Mercadal y el Movimiento Moderno. Tesis Doctoral. Madrid: Upm-Etsam.

Laborda Yneva, José (Ed.) (2008): Fernando García Mercadal. Artículos en la Revista Arquitectura 1920-1934. Zaragoza: Institución Fernando El Católico. (CSIC) Diputación de Zaragoza.

Layuno Rosas, Ángeles (2011): "Fernando García Mercadal. Tradición e Historia en la arquitectura de la modernidad". En: Chaves Martín, Miguel Ángel (ed.), Fernando García Mercadal. Arquitectura y fotografia. Una mirada al patrimonio arquitectónico de Segovia 1929-1936. Salamanca: Universidad Complutense de Madrid. Colegio de Arquitectos de Castilla y León Este, pp. 49-104.

Mangone, Fabio / Belli, Gemma / Tampieri, Maria Grazia (Eds.) (2015): Architettura e Paesaggio Delle Villeggiatura in Italia tra Ottocento e Novecento. Milano: Franco Angeli.

Moreno Villa, José (1931): “Sobre arquitectura popular”. En: Arquitectura, 146, Junio, pp. 187-193.

Pizza, Antonio (Ed.) (1997): Josep Ll. Sert y la cultura del Mediterráneo. Barcelona: Colegio de Arquitectos de Cataluña.

Ponzi, Mauro (a cura di) (2008): Spazi di transizione. Il Classico Moderno (1888-1933). Milán: Mímesis.

Pozo Municio, José Manuel (2010): "Viajar con brújula. A propósito de un viaje de García Mercadal y otro de Ortiz Echagüe". En: Viajes en la transición de la arquitectura española hacia la modernidad. Actas Preliminares. Pamplona: Escuela Técnica Superior de Arquitectura. Universidad de Navarra. 
Rodríguez Ruiz, Delfín (2003): "Fernando Garcia Mercadal. La arquitectura y el mar". En: Roma y la tradición de lo nuevo. Diez artistas en El Gianicolo (1923-1927), (Catálogo). Madrid: Sociedad Estatal para la Acción Cultural Exterior, pp. 132-143.

Sambricio, Carlos (1983): Cuando se quiso resucitar la arquitectura. Murcia: Colegio Oficial de Aparejadores y Arquitectos Técnicos. Galería Yerba.

Sambricio, Carlos (1984): "Las promesas de un rostro: Madrid 1920-1940. De la metrópolis al plan regional”. En: Madrid, urbanismo y gestión municipal 1920-1940. Madrid: Ayuntamiento de Madrid.

Sambricio, Carlos (2004): Madrid, vivienda y urbanismo: 1900-1960: de la "normalización de lo vernáculo" al plan regional. Madrid: Akal.

San Antonio Gómez, Carlos de (Ed.) (2001): Revista Arquitectura (1918-1936), Madrid: COAM, Ministerio de Fomento.

Semerani, Luciano (dir.) (1982): 1781-1841. Schinkel. L'Architetto del príncipe. Venecia: Albrizzi Editore/Cluva Librería Editrice.

Tafuri, Manfredo y Dal Co, Francesco (1989): Arquitectura contemporánea. Madrid: Aguilar/Asuri.

Talamona, Marida (2004): "Le Corbusier a Capri: réflexions sur 1'architecture traditionelle et le paysage”. En: Vv.Aa., Le Corbusier, la nature. París: Éditions de la Villete. Fondation Le Corbusier, pp. 184-193.

Torres Balbás, Leopoldo (1922): “Glosas a un álbum de dibujos”. En: Arquitectura, año IV, 40.

Torres Balbás, Leopoldo (1923): "La enseñanza de la historia de la arquitectura”. En: Arquitectura, 46, pp. 36-40.

Zurko, Edward R. de (1970): La teoría del funcionalismo en la arquitectura, Buenos Aires: Nueva Visión.

Fecha de recepción: 17-XI-2018

Fecha de aceptación: 10-IV-2019 